\title{
ROUNDTABLE SESSION 4 \\ THE IMPORTANCE OF PUBLIC EDUCATION FOR THE EFFECTIVE CONSERVATION OF EUROPEAN NATIVE CRAYFISH
}

\author{
J.D. REYNOLDS (1), AND M. PUKY (2)
}

(1) Department of Zoology, University of Dublin, Trinity College, DUBLIN 2, Ireland. E-Mail: jrynolds@tcd.ie

(2) Hungarian Danube Research Station of the Institute of Ecology and Botany, Hungarian Academy of Sciences, 2131 GOD, Javorka S: u. 14., Hungary. E-Mail: h7949puk@ella.hu

Reçu le 30 mai 2005

Received May 30, 2005

\begin{abstract}
Most current approaches to conservation focus on wide dissemination of information to the public. However, specific educational programmes are mostly lacking for Austropotamobius torrentium, which occurs in at least 19 countries of central and Eastern Europe and is often found outside Natura 2000 protected sites. A coordinated series of regional leaflets on its biology, role as environmental indicator and heritage importance is needed. A questionnaire on public awareness of crayfish across Europe showed major regional differences. Scandinavian countries, where crayfish are important economically and socially, generally showed greatest public awareness, reinforced by easily available documentation. Elsewhere, availability of information is patchy or non-existent. To generate awareness and help counter loss of native stocks, basic information should be accurate and widely available across Europe, both for decision makers and the general public.
\end{abstract}

Key-words: crayfish, Austropotamobius torrentium, education, information, conservation.

TABLE RONDE 4

\section{L'IMPORTANCE DE L'ÉDUCATION DU GRAND PUBLIC POUR LA CONSERVATION} EFFECTIVE DES ÉCREVISSES NATIVES EUROPÉENNES

\section{RÉSUMÉ}

La plupart des approches relatives à la conservation reposent sur la vaste dissémination d'information au grand public. Néanmoins, la plupart des programmes spécifiques d'éducation n'existent pas en ce qui concerne Austropotamobius torrentium, espèce répandue dans au moins 19 pays de l'Est et du Centre de l'Europe, et souvent en dehors des sites protégés de Natura 2000. Une série coordonnée d'imprimés aussi bien sur sa biologie que sur son rôle comme bioindicateur et symbole de patrimoine est absolument nécessaire. Un questionnaire sur la prise de conscience du public en ce qui concerne les écrevisses à travers l'Europe a montré des différences régionales importantes. En Scandinavie, où les écrevisses ont une valeur économique et sociale, la prise de conscience est plus forte, et renforcée par de la documentation facilement disponible. Ailleurs, la documentation est peu disponible ou n'existe pas. Pour engendrer une prise de conscience, et pour lutter contre la disparition des populations natives, 
l'information de base doit être exacte, et diffusée largement à travers toute l'Europe, à la fois au niveau des décideurs et du grand public.

Mots-clés : écrevisses, Austropotamobius torrentium, éducation, information, conservation.

\section{INTRODUCTION}

Public natural history education has developed greatly in the past 30 years. The earlier idea that most people are best kept in ignorance of the existence of a rare species or excluded from an important site, has given way to today's approach of encouraging public education through wide dissemination of information, in the belief that the species or habitat stands an improved chance of survival if many are concerned and aware. Discussions now focus, for example, on which section of the public to target, and which approach is most likely to bear fruit (for crayfish, see, for example, PUKY et al., 2002).

The CRAYNET Roundtable discussion on education at the Innsbruck Meeting drew on ideas and developments in other recent crayfish meetings, including Poitiers (SOUTYGROSSET and GRANDJEAN, 2002), Kilkenny (REYNOLDS and SOUTY-GROSSET, 2004), Halden (EDSMAN et al., 2004) and London (IAA XV Congress, London, September 2004). There already exist many good examples of public awareness campaigns on crayfish across Europe; thus the present priority must be to assess their effectiveness and to find out whether the diversified approach suited to each specific region can be merged into a Europe-wide, coordinated strategy.

In this roundtable discussion, two main topics were presented. The meeting concentrated first on the specific situation of the stone crayfish, Austropotamobius torrentium, and considered how best to educate the public about its existence and status wherever it occurs. Secondly, the meeting looked more widely at the present state of public knowledge about crayfish across Europe. The first topic was elicited in discussion and the second, through a questionnaire approach. Finally, discussion centred on the importance of accurate information both for the public and for accurate briefing of policymakers and implementation of legislation.

\section{KNOWLEDGE ABOUT AUSTROPOTAMOBIUS TORRENTIUM}

It was clear from the Innsbruck meeting that knowledge of $A$.torrentium had greatly increased, and that much had been formulated for publication, often within a broader European context. There is now a reasonable picture of its distribution and preferred habitats in circum-alpine countries (see, for example, PÖCKL and STREISSL, PUKY et al., STLOUTAL and HARVANEKOVA, FÜREDER, and others, this volume). The stone crayfish is however also widely distributed in central and eastern Europe, and participants represented knowledge about it in nineteen countries: Albania, Austria, Bosnia-Herzegovina, Bulgaria, Czech Republic, Croatia, France, Germany, Greece, Hungary, Italy, Liechtenstein, Luxembourg, Romania, Serbia and Montenegro, Slovakia, Slovenia, Switzerland and Turkey.

Discussion was centred on a series of four questions, although not all could be explored in detail given the short time available.

The first question considered was: do stone crayfish chiefly live in high quality habitats that are already protected, formally or informally? This has relevance in deciding how best to direct information about it to the public.

Responses to this question were varied. A.torrentium certainly lives in such habitats, both lakes and streams, but may also be found in less pristine waters, 
comparable in some opinions to those of $A$. pallipes. Also, as SACs (Natura 2000 sites) do not cover all countries, many stocks existed which do not have protection through the habitats. Populations appear to be patchier and the biotopes more threatened in the west of its distribution, than in the east. It was noted that there exists currently no European legislation protecting this species. Discussion on this was further developed in other roundtable sessions (see HOLDICH and PÖCKL, 2005 and SOUTY-GROSSET, SCHULZ and MADEC, 2005).

\section{Secondly, how well known is the stone crayfish, in the regions where it lives?}

In general, there seems to be good knowledge about this crayfish in most circumalpine countries. While individuals reach a similar size to that of $A$. pallipes, there was no indication of commercial exploitation, although there is some recreational fishing.

\section{Thirdly, what educational material or programmes exist for this species?}

In general, participants indicated that such programmes are lacking though exceptions can also be found. In Hungary, for example, a conservation-oriented survey was launched in the mid-1990s, involving the publication of a crayfish survey manual with detailed general, conservational and methodological information, including some on A. torrentium (HARSÁNYI and ROGOVSZKY, 1996).

Finally, what scope is there for further educational programmes aimed specifically at $\boldsymbol{A}$. torrentium, and more generally, at all European crayfish?

The concensus was that specific educational programmes should be developed for this restricted species. How these were to be done, needed much further discussion, and the answers are likely to be country-specific. Several participants provided examples of educational material from their countries, and the second part of the question led into the presentation of the Questionnaire results.

\section{QUESTIONNAIRE SURVEY: CURRENT STATE OF PUBLIC AWARENESS OF CRAYFISH IN EUROPE}

To gain a European overview on public education on crayfish, participants at the Innsbruck Meeting were asked, as an expert group, to fill in a questionnaire on this topic (Table I) before the roundtable began. Altogether 27 responses representing 15 countries were returned to the organizers, over one third of those consulted, which is in line with expected proportions for the personal approach of the method (for details on efficiency differences between PR methods, see PUKY and VOGL, 2003) and the dedication of the target group. All gave countries of origin; names of respondents were supplied in $75 \%$ of cases. When more than one representative of a country completed a questionnaire, average values were used to characterize the country, irrespective of the age, experience, etc. of the respondents. Due to the small sample size, no detailed analysis was made either during the workshop or afterwards. Instead, extremes, similarities and dissimilarities were discussed during the presentation and the subsequent discussion of the first crayfish expert group opinion poll.

There are important differences in level of knowledge of the general public on crayfish in different European countries (Figure 1), which has consequences for their ability to influence politicians and policy-makers. Scandinavian countries are ahead of other nations in this respect, mainly as a consequence of the wide-scale exploitation of crayfish (historically Astacus astacus), which is a living tradition in all these countries. People in the UK are also quite aware of crayfish in general. In countries such as France, Germany and Poland, most people cannot discriminate between species. Ireland, on the other hand, is one of the countries at the other extreme in this respect, where people are likely to ask 


\section{Table I}

Questionnaire on the knowledge and education of the European public on crayfish issues, 2004.

Tableau I

Questionnaire sur la connaissance et l'éducation du grand public européen sur les écrevisses, 2004.

\section{CRAYNET THEMATIC MEETING, INNSBRUCK SEPTEMBER 04 \\ ROUND TABLE - EDUCATION OF THE PUBLIC - QUESTIONNAIRE}

Dear Meeting Participant,

Whether or not you intend to participate in our Round Table, we would be most grateful if you would take a few minutes to share your knowledge of public attitudes to crayfish.

COUNTRY:

NAME (optional):

1. In your country, how much does the general public know about crayfish? Rank from 1 (practically nothing) to 5 (well informed about details).

COMMENTS:

2. How much is the general public aware in your country about the threatened status of endemic crayfish species?

Rank from 1 (not at all) to 5 (well aware).

COMMENTS:

3. How much information is available on crayfish in your country for the general public?

Rank from 1 (practically nothing) to 5 (a lot).

COMMENTS:

4. What material has been produced specifically on crayfish in your country (e.g. films, posters, leaflets, etc.) for the general public on local crayfish?

What would be needed to improve the situation?

5. What is the ratio of alien to endemic crayfish in your country?

\section{OTHER COMMENTS:}

Many thanks,

Miklos PUKY, Julian REYNOLDS (Workshop organisers).

PLEASE LEAVE YOUR COMPLETED FORM AT THE REGISTRATION DESK. 


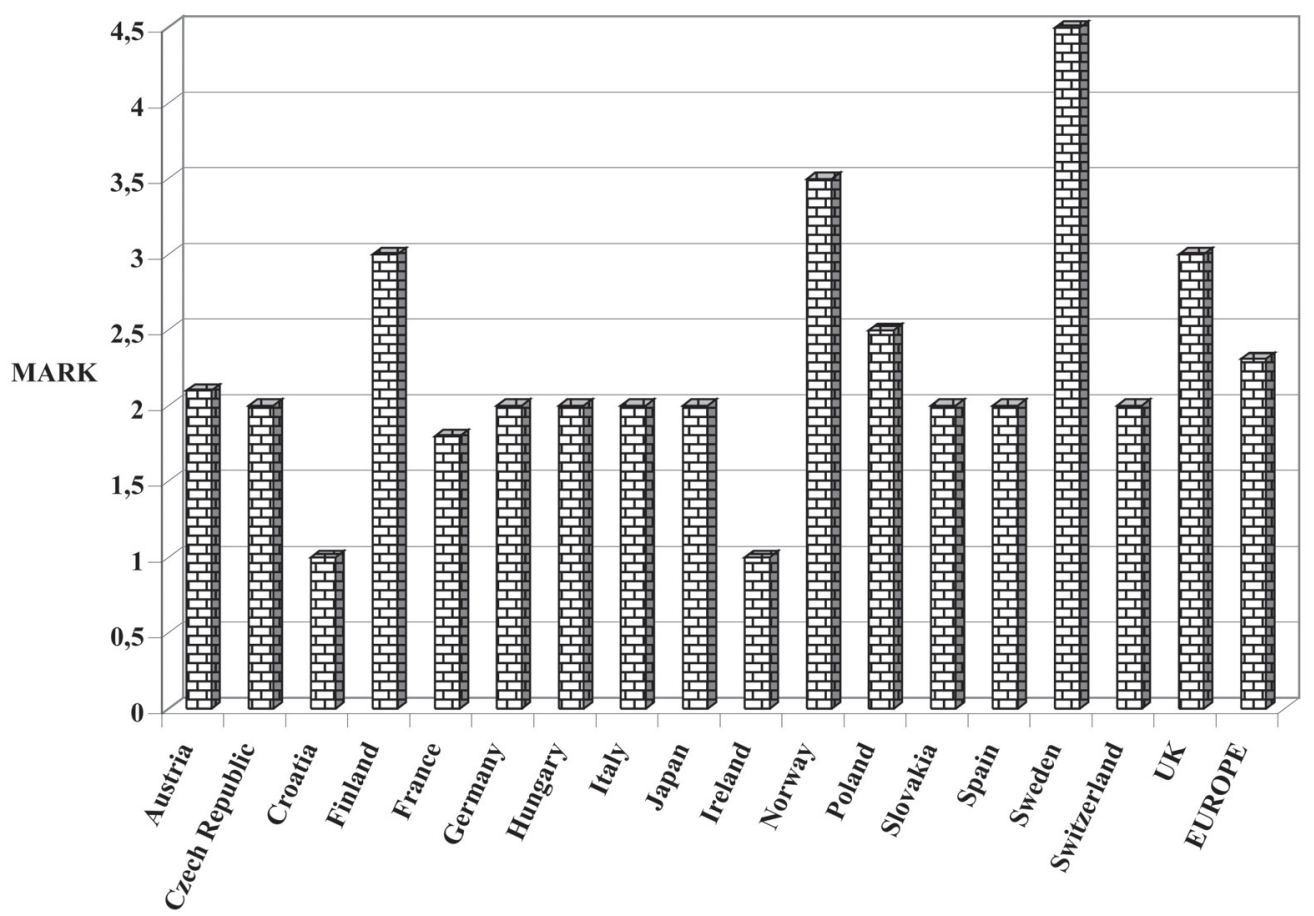

COUNTRY

Figure 1

Public knowledge about crayfish in general in different European countries in 2004.

\section{Figure 1}

Niveau de connaissance du public sur les écrevisses en général dans les différents pays européens, 2004.

researchers what sort of a fish is a crayfish. This is probably related to the lack of any utilization of the only species, Austropotamobius pallipes, which is small in comparison with $A$. astacus. The other is Croatia, where, because of civil war in the last decade, little attention could be directed towards crayfish.

The threatened status of non-native crayfish species is well known in Sweden, Norway, the Czech Republic and the UK (Figure 2). In many countries there is confusion between alien and native species. As the UK has problems arising from expanding populations of alien crayfish, this recognition also indicates the spread of American species across the country. In Scandinavia the American alien species Pacifastacus leniusculus has exerted pressure on local populations of $A$. astacus, thus leading to an increased recognition of this problem. However, Finland appears to differ strikingly from the rest in the perceived level of awareness. The general public in Croatia, Ireland and Hungary are also rather ignorant about the fact of crayfish invasions. While this is easily understandable in Ireland, with only a single native species and no aliens, in Hungary, where there are three native and three alien species, information needs to be disseminated fast in an effort to stop deliberate introductions. General information on crayfish is most available in Finland, Austria and Sweden according to the conference participants (Figure 3). Other countries, such as Germany, Italy, the UK, also have a lot of information material. As an example, in Germany there are public relations initiatives on crayfish in the states of Baden-Wuertemberg, Bavaria, Brandenburg, Lower Saxony, North Rhine- 


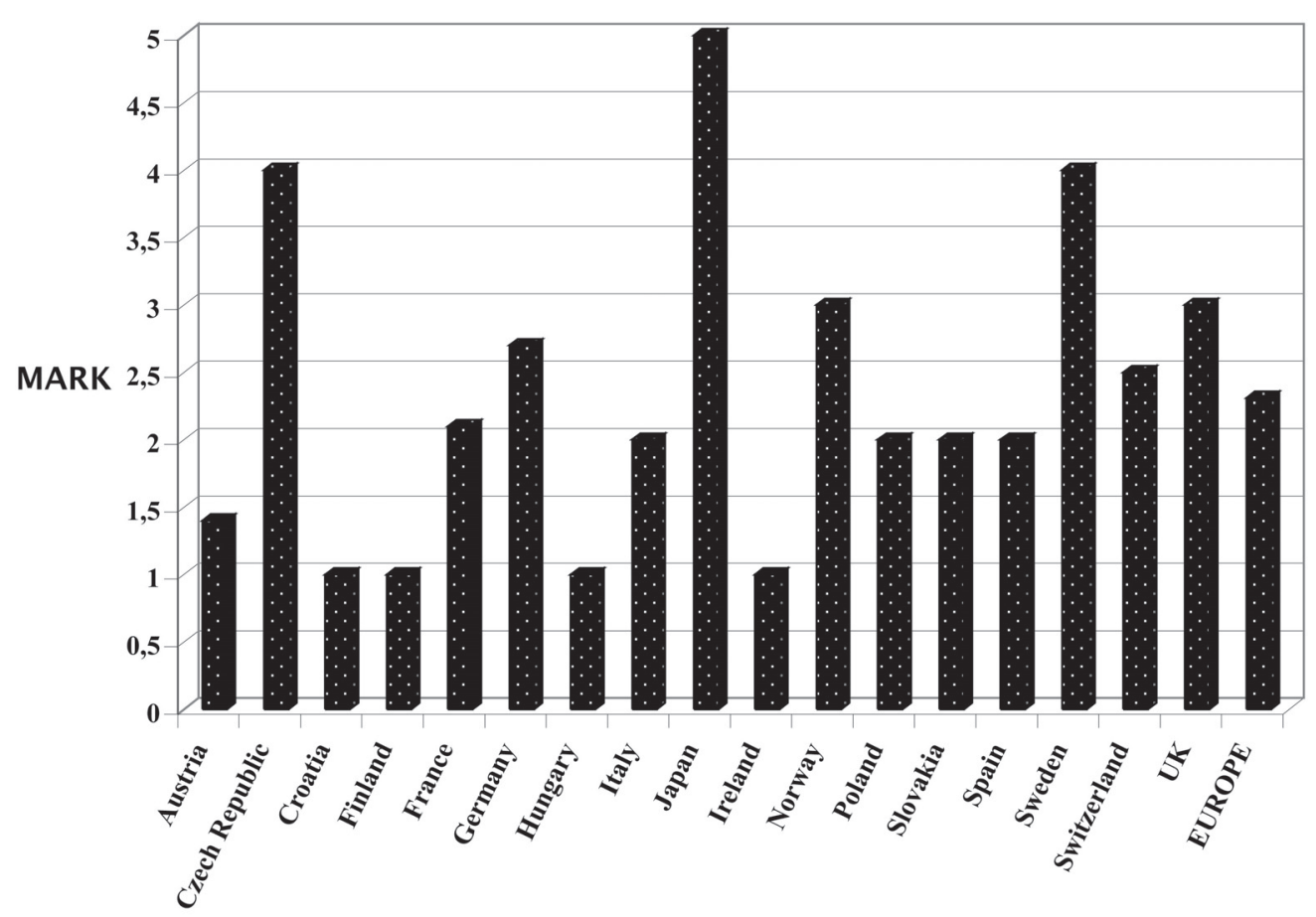

COUNTRY

Figure 2

Public knowledge about the threatened status of native crayfish species in different European countries in 2004.

Figure 2

Niveau de connaissance du public sur l'état de la menace pesant sur les écrevisses natives dans les différents pays européens, 2004.

Westphalia, Saarland and Saxony-Anhalt, nearly half of the federal states, while there is still much to do in Hungary, Ireland, France and Spain in this respect.

The discussion also indicated regional differences within certain countries, such as Germany, France and Spain, and brought up special conservation approaches such as the example of Szczecin, Poland, where native and alien crayfish species (Astacus astacus, Orconectes limosus) are introduced to the general public in a 60 page colour tourist brochure describing recreational opportunities in the area. Most cleverly, the short descriptions and crayfish pictures were put on a page facing a photo of a beautiful sunset, catching the attention of the reader and thus spreading crayfish information even more effectively.

So, what types of public information would best suit the specific case of A. torrentium, as well as the more general case? Which sectors of the public should be targeted? In some Austrian states the fishing public must first pass a specific examination, encompassing biological and ecological information as well as fishing methods and legislation. In Salzburg, thereafter, all licensed fishermen receive a quarterly newsletter in which awareness can be enhanced. Such a situation would allow information to be transmitted in a timely fashion on specific issues, such as reasons for size limits and closed seasons, or responsible actions to halt the spread of alien crayfish. Another approach was exemplified by Sweden, where the start of the crayfish fishing season was marked by extensive colour supplements in the national papers, containing information, 


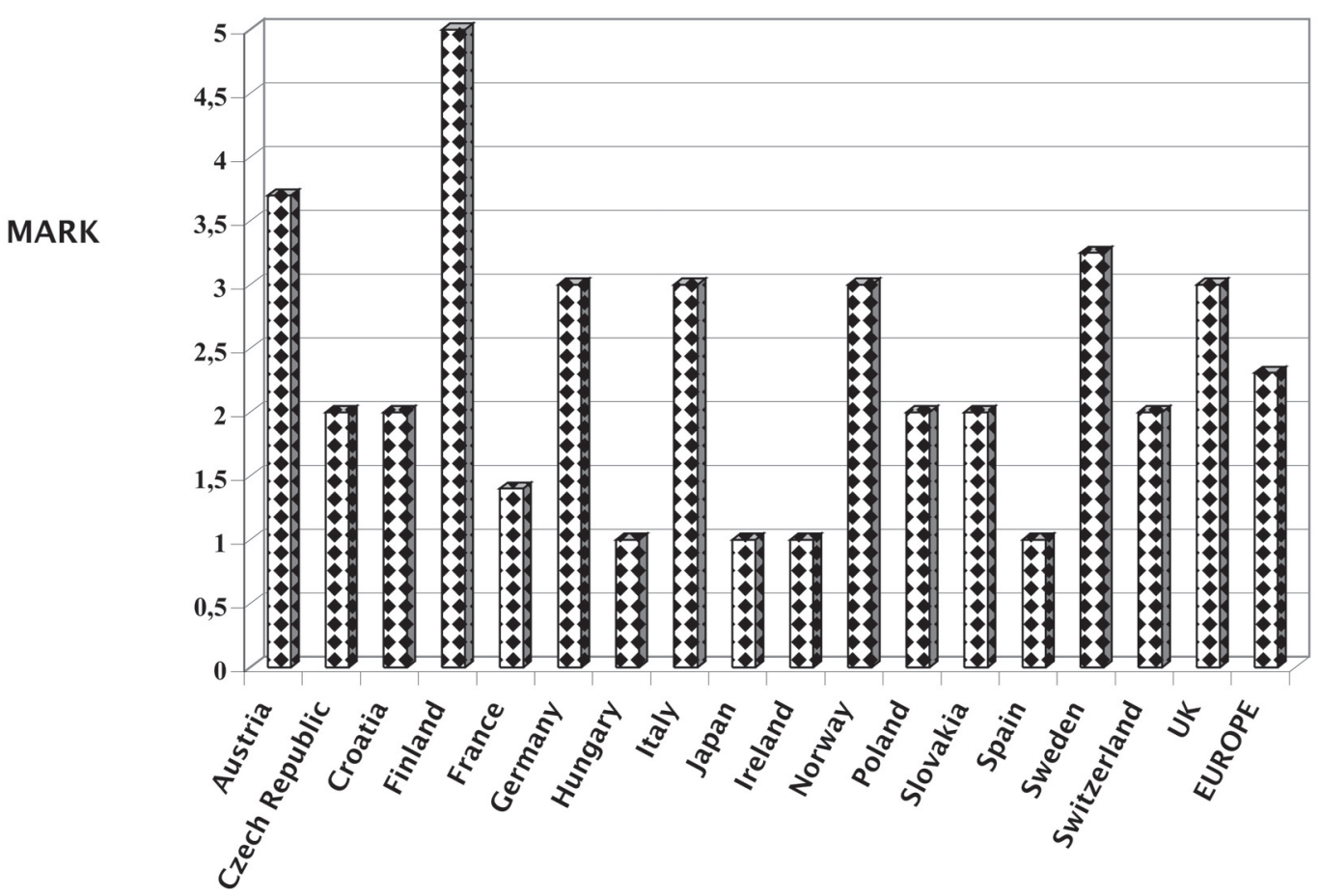

COUNTRY

Figure 3

Information available on crayfish in different European countries in 2004.

Figure 3

Information disponible sur les écrevisses dans les différents pays européens, 2004.

recipes, advertisements for barbecue necessities, etc. If the information contained is correct, such supplements can educate and influence a very wide audience, but the associated commerce must be able to support it.

\section{CONCLUSION}

In regard to the first topic discussed by the roundtable, we conclude that where there currently exists almost no educational material available to the public and directed specifically at Austropotamobius torrentium, this provides a unique opportunity to develop a common programme of education and conservation for this widely distributed species. We recommend initially developing a series of leaflets for widest possible diffusion and in various languages, on the biology of the stone crayfish - where it occurs, and in what habitats; its life cycle, its significance as a heritage species, and why we should conserve it as a symbol of a good quality environment. At the same time, it is important that its legal status should be clarified and strengthened.

Secondly, in terms of native European crayfish in general, it is apparent that a varying degree of knowledge exists among the public in different regions. However, even where the level of information is high, as in Sweden, it may be imperfect and in some cases even incorrect. Elsewhere, although leaflets may exist, in many cases they may not be widely distributed. In the UK, for example, the public may have to request such information, which presupposes a prior level of awareness and enthusiasm. Such enthusiasm cannot 
easily be generated and spread in such situations, and it was evident from participants that more information was needed, presupposing more resources.

It was also clear that most people are pessimistic about the future for native crayfish. To change such attitudes and generate awareness and concern, information must be accurate, widely available, and regularly updated. There should be an interestspecific approach, targeting those not interested as well as those already involved. The general public needs interesting stories rather than local issues, while politicians should receive a concise, easy message with suggested action points. The importance of 'bad news stories' (for instance, on plague, which underline the need for recognition of plaguespreading species) was emphasized. Through all these approaches, there is a better chance for significant numbers of the public to find their own voice and, with increasing confidence, to shout loud.

Given the importance of reaching the public and, through them, politicians and decision-makers, participants suggested various means of improving public knowledge. These range from information campaigns aimed at specific target groups such as environmental and fishery managers (France), greater use of television (Poland) and the web (France, Austria), exhibitions and excursions (Switzerland) and regular and accurate newspaper briefings (Germany, Spain), to talks in schools (France, Germany, Ireland) and even prosecution of those who infringe the law (UK). Legislation ought to help in protecting native crayfish, but may not always do so if its correct implementation is difficult. For example, state veterinarians and customs officers have a crucial role to play, as do wildlife inspectors and water managers, but if they cannot recognize the species named in the legislation in order to take appropriate action, the law is useless. To prevent this, information must be directed specifically at such officers; while this need not necessarily be different from material for the general public, it must set a high standard of accuracy and clarity of identification.

Finally, we have identified possible topics for a number of common European leaflets, which could be translated into various languages, as follows:

1. Identify your crayfish;

2. Statutory protection of European native crayfish species;

3. Crayfish and biodiversity;

4. Dealing with alien species;

5. The facts about crayfish plague - how you can help;

6. Monitoring native crayfish;

7. Conservation approaches for native crayfish;

8. Harvesting crayfish - problems and potential.

\section{ACKNOWLEDGEMENTS}

The organizers particularly wish to thank all participants in this roundtable. We are most grateful to those who provided publicity material or other information on crayfish from their countries, in particular, Max Keller and the Forum Flusskrebse, David Holdich, and Holger Schulz.

\section{REFERENCES}

EDSMAN L., TAUGBØL T., SOUTY-GROSSET C., 2004. Preface. In: TAUGBØL T. and SOUTY-GROSSET C., 2004: European native crayfish with a special focus on Astacus astacus: linking socioeconomics and conservation, CRAYNET, Volume 2. Bull. Fr. Pêche Piscic., 372-373, 233-239. 
FÜREDER L. and SOUTY-GROSSET C., 2005: European native crayfish in relation to landuse and habitat deterioration with a special focus on Austropotamobius torrentium, CRAYNET, Volume 3. Bull. Fr. Pêche Piscic., 376-377, 357 p.

HARSÁNYI T., ROGOVSZKY Z., 1996. Fogadi örökbe egy patakot! 4: Rákfelmeres, Kutatástervezes és adatfeldolgozás (Adopt a stream! 4: Crayfish monitoring, research plan and data processing). Fiatalok Természetismereti Klubja and Göncöl Alapítvány. Budapest, Vác. 108 p.

HOLDICH D.M., PÖCKL M., 2005. Roundtable session: Does legislation work in protecting vulnerable species? In: FÜREDER L. and SOUTY-GROSSET C., 2005: European native crayfish in relation to land-use and habitat deterioration with a special focus on Austropotamobius torrentium, CRAYNET, Volume 3. Bull. Fr. Pêche Piscic., 376377, 809-828.

PÖCKL M., STREISSL F., 2005. Austropotamobius torrentium as an indicator for habitat quality in running waters. In: FÜREDER L. and SOUTY-GROSSET C., 2005: European native crayfish in relation to land-use and habitat deterioration with a special focus on Austropotamobius torrentium, CRAYNET, Volume 3. Bull. Fr. Pêche Piscic., 376-377, 743-758.

PUKY M., REYNOLDS J.D., SCHÁD P., 2005. Native and alien decapoda species in Hungary: distribution, status, conservation importance. In: FÜREDER L. and SOUTY-GROSSET C., 2005: European native crayfish in relation to land-use and habitat deterioration with a special focus on Austropotamobius torrentium, CRAYNET, Volume 3. Bull. Fr. Pêche Piscic., 376-377, 553-568.

PUKY M., VOGEL ZS., 2003. Amphibian mitigation measures on Hungarian roads: design, efficiency, problems and possible improvement, need for a coordinated European environmental education strategy. Proceedings IENE Conference 2003, 1-11. Institute of Nature Conservation, Bruxelles.

PUKY M., REYNOLDS J.D., GRANDJEAN F., 2002. Education as a key to decapod conservation. Bull. Fr. Pêche. Piscic., 367, 911-916.

REYNOLDS J.D., SOUTY-GROSSET C., 2003. The endangered native crayfish Austropotamobius pallipes, bioindicator and heritage species. CRAYNET, Volume 1. Bull. Fr. Pêche Piscic., 370-371, 230 p.

SOUTY-GROSSET C., GRANDJEAN F., 2002. Knowledge-based management of European native crayfish. Crayfish special Volume 4. Bull. Fr. Pêche Piscic., 367, 402 p.

SOUTY-GROSSET C., SCHULZ R., MADEC J., 2005. Roundtable: Crayfish protection programmes in Europe 2005. In: FÜREDER L. and SOUTY-GROSSET C., 2005: European native crayfish in relation to land-use and habitat deterioration with a special focus on Austropotamobius torrentium, CRAYNET, Volume 3. Bull. Fr. Pêche Piscic., 376-377, 797-808.

STLOUKAL E., HARVANEKOVA M., 2005. Distribution of Austropotamobius torrentium (Decapoda, Astacidae) in Slovakia. In: FÜREDER L. and SOUTY-GROSSET C., 2005: European native crayfish in relation to land-use and habitat deterioration with a special focus on Austropotamobius torrentium, CRAYNET, Volume 3. Bull. Fr. Pêche Piscic., 376-377, 547-552. 
